\title{
A nukleáris taktikai fegyverek olaszországi állomásoztatásának kül- és biztonságpolitikai kérdései
}

\begin{abstract}
Olaszországban az ötvenes évek óta amerikai nukleáris taktikai fegyvereket állomásoztatnak. A hidegháború alatt az atomfegyverek befogadásában Róma a nemzetközi rang növelésének eszközét látta, bízva abban, hogy lehetőséget biztosít az ország irányában a második világháború alatt megrendült nemzetközi bizalom helyreállitására. A bipoláris rendszer belpolitikai hatásai miatt az atomfegyverek befogadása biztosította a kifejezetten erős támogatottságot élvező Olasz Kommunista Párt ellenzékben tartását. Bár a hidegháború végével az atomfegyverek olaszországi állomásoztatásának eredeti indokai eltüntek, Olaszország mégsem tesz aktív lépéseket a leszerelésükre.
\end{abstract}

Kulcsszavak: Olaszország, Egyesült Államok, nukleáris fegyverek, leszerelés, NATO

\begin{abstract}
Takács Lili: Current Foreign and Security Policy Issues Regarding Stationing Nuclear Tactical Weapons in Italy

Italy has been storing U.S. nuclear tactical weapons since the 1950s. During the Cold War, Rome considered hosting nuclear weapons a tool to strengthen the international ranking of the country, hoping that it provides an opportunity to restore trust in Italy's international image, which had been shaken by World War II. As a consequence of the effect of bipolar logic on Italian domestic politics, hosting nuclear weapons guaranteed that the Italian Communist Party remained in opposition. Although the original reasons of hosting U.S. nuclear weapons have disappeared at the end of Cold War, Italy is not actively promoting nuclear disarmament.
\end{abstract}

Keywords: Italy, United States, nuclear weapons, nuclear disarmament, NATO

\section{Bevezetés}

A NATO 2010. november 19-én Lisszabonban elfogadott stratégiája szerint az Északatlanti Szövetség célja a nukleáris fegyverek nélküli világ megteremtése, a koncepció azonban hangsúlyozza, hogy amíg léteznek nukleáris fegyverek, addig a NATO nukleáris szövetség marad. Európában a szövetség két európai nukleáris nagyhatalmán (NagyBritannia, Franciaország) kívül öt NATO-tagállam - Belgium, Németország, Hollandia, Törökország és Olaszország - területén is amerikai nukleáris taktikai fegyvereket állomásoztatnak az előretolt jelenlét (forward-deployment) keretében. Az elmúlt években számos vita bontakozott ki az Egyesült Államokban és Európában a taktikai nukleáris fegyverek megváltozott nemzetközi biztonsági környezetben való alkalmazhatóságáról. A taktikai nukleáris fegyverek száma Európában a hidegháború vége óta drasztikusan csökkent, 
további csökkentésük és az európai országok területéről való teljes kivonásuk élénk viták tárgyát képezik napjainkban is.

Bár a becslések szerint a fent felsorolt öt ország közül valószínűleg Olaszországban állomásoztatják a legtöbb nukleáris töltetet, illetve ez az egyetlen ország, ahol két nukleáris bázis is található, a kérdéskörrel kapcsolatos olasz álláspont kevéssé ismert. A tanulmány célja az Olaszországban állomásoztatott nukleáris taktikai fegyverekkel kapcsolatos politikai nézőpont bemutatása, kiemelve ennek kül- és belpolitikai dimenzióit és az ebben bekövetkezett változásokat.

\section{Az Olaszországban állomásoztatott nukleáris taktikai fegyverek típusai és azok változása}

A hidegháború teljes időszaka alatt Olaszország az egyik legjelentősebb nukleáris bázis volt Nyugat-Európában, a nukleáris hatalom Nagy-Britannia és Franciaország, valamint a Német Szövetségi Köztársaság mellett, az ötvenes évek közepétől amerikai nukleáris fegyvereket állomásoztattak olaszországi katonai bázisokon. Jogi szempontból a NATO alapokmánya szerint a tagállamok a szövetség rendelkezésére bocsáthatnak katonai bázisokat, amennyiben a szervezet az adott tagállammal erről szerződést köt. Ezekkel párhuzamosan léteznek az Egyesült Államokkal kötött bilaterális szerződés alapján létrehozott amerikai katonai bázisok. ${ }^{1}$ Nem mindig egyértelmü, hogy egy bázis NATO- vagy amerikai bázisként kategorizálható, mert előfordul, hogy a NATO-bázison belül is találhatók az Egyesült Államok hadereje számára fenntartott területek, amelyek vegyes használatú bázisnak tekinthetők, a NATO Alapokmány 3. cikkelyének ${ }^{2}$ „bilateralizálása” alapján. Harmadik kategóriába sorolhatók a tisztán olasz bázisok, amelyeket a szövetség rendelkezésére bocsáthatnak - például a tarantói haditengerészeti bázist a tagállamok hadihajói ellátmányuk pótlása céljából használhatják.

Az olasz állam területére 1957-ben érkeztek először nukleáris fegyverek, amikor az ország északkeleti részén állomásozó amerikai katonai egység, a Southern European Task Force $(\mathrm{SETAF})^{3}$ által felügyelt Corporal és Honest John rakéták kaptak nukleáris robbanófejeket. A SETAF 1955-ös felállítását megelőző tárgyalások az olasz és az amerikai fél számára is precedenst képeztek a jövőbeli, hasonló tárgyalásokhoz. Olaszország egyrészről arra törekedett, hogy a megegyezést ne olasz-amerikai bilaterális megállapodásként, hanem multilaterális, NATO-kezdeményezés eredményeként mutassa be, hogy a lehetséges ellenséges reakciókat csökkentse; másrészről pedig az amerikai csapatok vendégül látása

Tekintettel arra, hogy a katonai bázisok alapító szerződései minősítettek, kevés nyílt információ érhető el. 2006 szeptemberében az akkori olasz védelmi miniszter, Arturo Parisi a Képviselőházban tartott felszólalásában nyolc darab Olaszországban található amerikai katonai bázisról beszélt, amelyek a következők lehetnek: a capodichinói katonai reptér; az avianói és pordenonei repterek; Camp Derby; gaetai bázis; Isola della Maddalena-i bázis; sigonellai haditengerészeti támaszpont; San Vito dei Normanni-i obszervatórium; longarei bázis.

Lásd: Natalino Ronzıтti: Le basi americane in Italia - problemi aperti, Dossier per il Senato della Repubblica, XV $\mathrm{L}^{\circ}$ gislatura, 2007/70, 2-11. o.

„A jelen szerződésben kitüzött célok hathatósabb elérése érdekében a Felek külön-külön és együttesen, folyamatos és hathatós önsegély és kölcsönös segítség útján, fenntartják és kifejlesztik egyéni és kollektív védelmi képességüket fegyveres támadással szemben."

3 Southern European Task Force (SETAF), [online]. Forrás: Globalsecurity.org [2018. 12. 23.] 
jelentette gazdasági terhek csökkentése és kompenzációként az olasz fegyveres erők fejlesztésének támogatása volt a cél. Ki kell emelni, hogy az olasz kormány a SETAF felállításakor tisztában volt azzal, hogy az új SETAF egységek esetleg már akkor is, de a jövőben minden bizonnyal taktikai nukleáris fegyverekkel lesznek felszerelve. ${ }^{4}$ A SETAF nukleáris erői a konfliktus kirobbanásának első szakaszában lettek volna bevetve, feladatuk a Varsói Szerződés offenzívájának lelassítása, illetve az olasz haderő teljes mozgósításának megkönnyítése lett volna.

1959 és 1960 között harminc darab, úgynevezett „kétkulcsos” (a doppia chiave), közepes hatótávolságú, 1,45 megatonnás, termonukleáris robbanófejekkel felszerelt Jupiter rakétát telepítettek Olaszországba az amerikai nukleáris arzenál modernizálásának keretében, amelyet Eisenhower kormánya indított el. A rakétákat a kubai rakétaválság után kb. fél évvel, 1963 áprilisában szerelték le. A hatvanas évek elejétől Olaszország különböző nukleáris taktikai fegyvereket fogadott be, többek között W-31-es atomrobbanófejekkel felszerelt, 2, 20, és 40 kilotonnás Nike Hercules légelhárító rakétákat, tüzérségi lövedékeket, az északkeleti határ mentén elásott romboló atomaknákat, gravitációs bombákat és különböző kettős felhasználású fegyvereket, például Starfighter vadászbombázókat. ${ }^{5}$

A nukleáris telepítés csúcspontját az úgynevezett eurorakéták comisói bázisra való telepítése jelentette 1983-1987 között. Az olasz parlament jóváhagyta a NATO 1979-es, úgynevezett kettős határozatát, ${ }^{6}$ így új generációs Cruise és Pershing rakéták érkeztek az országba, a szovjetek által 1976-ban telepített, közepes hatótávolságú SS-20-as ballisztikus rakétákra válaszul. Az eurorakétákat 1987-ben vonták ki Olaszországból - és Európából -, miután Ronald Reagan és Mihail Gorbacsov aláírta a közepes hatótávolságú nukleáris erőkről szóló szerződést (Intermediate-Range Nuclear Forces Treaty), amelyben az összes közepes és rövidebb hatótávolságú nukleáris fegyver leszereléséről döntöttek.

A hidegháború végén az európai NATO-tagállamokban állomásoztatott több ezer amerikai nukleáris fegyvert az USA drasztikusan lecsökkentette, 1991-re már csak 150-200 darab B-61-es gravitációs bomba maradt Európa területén, ami nagyjából megegyezik a mai számukkal. A becslések szerint 60-90 B-61-es bombát állomásoztathatnak jelenleg Olaszországban, de ezekről pontos információk nyílt forrásokon nem találhatók. Napjainkban a ghedi torei bázison állomásoztatnak B-61-es bombákat, amelyeket a PA200 Tornadókkal tud hordozni az olasz 6. repülőezred, ezek hivatalosan az amerikai légierö 704. támogató százada (704th Munitions Maintenance Squadron) felügyelete alatt vannak. Avianóban a feltételezések szerint 60-70 B-61-es bomba lehet, amelyet az amerikai légierö 31. repülöezredének F-16C/D vadászbombázói hordoznak.7

A nukleáris bombák szállításához Olaszország Tornado vadászbombázókkal rendelkezik, azonban ezek egyrészt hamarosan elérik müködési élettartamuk végét, másrészt pedig a legújabb, B-61-12-es bombák minden lehetőségének kihasználásához az F-35A

Leopoldo Nuti: Italy's nuclear choices, UNISCI Discussion Papers, 2011/25, 170-172.

Paolo ForADORI: Reluctant disarmer: Italy's ambiguous attitude toward NATO's nuclear weapons policy, European Security, 23. évf., 2014/1, 33-36. o.

6 A kettős döntésként ismertté vált határozat egyrészt új rakéták Európába telepítéséről döntött, másrészt pedig ezzel a NATO kinyilvánította, hogy kész tárgyalásokat kezdeni a Szovjetunióval az SS-20-asok visszavonásáról.

Robert S. Norris - Hans M. Kristensen: US tactical nuclear weapons in Europe, Bulletin of the Atomic Scientists, 61. évf. 2012/1, 69. o. 
vadászbombázók képességei szükségesek, ami részben megmagyarázza Olaszország kettes szintű partneri részvételét az F-35-ös Joint Strike Fighter programban. ${ }^{8}$ Az F-35-ös vadászbombázók beszerzésének jelentősége a technikai ugrás, valamint harcászati képesség és generációváltás mellett tehát abban áll, hogy az eszközök olyan fejlett rendszerrel fognak rendelkezni, amely lehetővé teszi a B-61-12-es nukleáris taktikai töltetek integrálását a fegyverrendszerbe. ${ }^{9}$ Az olasz haderő számára beszerzésük egy olyan szükségszerüséget jelent, amelynek jelenleg a piacon nincs alternatívája. Az F-35-ösökkel szeretnék pótolni a légierő azon eszközeit (mintegy 240 AM-X, Tornado és AV8B), amelyek a következő kb. tizenöt évben elérik müködésük élettartamának végét.

\section{Nukleáris fegyverek állomásoztatása mint a nemzetközi rang növelésének eszköze a hidegháború alatt}

Olaszország számára a második világháború végén az ország gazdasági újjáépítése, politikai stabilitásának megteremtése mellett a büntető békeszerződés elkerülése volt a fö prioritás. A győztesek ugyanis a béketervezet összeállításakor alig vették figyelembe, hogy Olaszországban Róma felszabadulása után antifasiszta kormány alakult, valamint hogy az olaszok jelentös mértékben hozzájárultak saját maguk felszabadításához, így Olaszországra is lényegében büntető békeszerződés várt, ${ }^{10}$ aminek ellensúlyozása alapvetően meghatározta a második világháború utáni olasz külpolitikát.

A Hirosima és Nagaszaki elleni atomtámadás után élénk vita bontakozott ki mind a katonai, mind a civil olasz tudósok körében az új technológia kapcsán, egyetértve abban, hogy a nemzetközi rendszer új korszakhoz érkezett. A katonai és a civil szféra véleménye is megegyezett abban, hogy Olaszország nemzetközi rendszerben betöltött szerepét a nukleáris korszak beköszöntése hátrányosan fogja érinteni és fokozva a második világháború

\footnotetext{
A projektben való részvétel először 1996-ban, az első Prodi-kormány idején merült fel, konkrét kötelezettségvállalás azonban csak két évvel később született, amikor 1998. december 23-án a D’Alema kormány aláirta a tervezési és demonstrációs szakaszra vonatkozó egyetértési megállapodást, és egyben 10 millió dollárt fektetett be a projektbe. Az F-35 programban való további részvételt, azaz a fejlesztési szakaszban való részvételt a képviselőház és a szenátus védelmi bizottságainak jóváhagyása után a második Berlusconi-kormány 2002-ben megerősítette, ez akkor körülbelül 1190 millió euró költséget jelentett az olasz kormány számára. 2009. április 8-án mindkét védelmi bizottság jóváhagyta a kormány által benyújtott javaslatot, amelynek értelmében 12,9 milliárd euróért 131 darab F-35-ös vadászgép 2026-ig történő beszerzéséről határoztak. Az eredetileg beszerezni tervezett vadászgépek számát a haderő felülvizsgálatának és átalakításának részeként - illetve költségcsökkentési okokból - 2012-ben 131-röl 90-re csökkentették, 2018 szeptemberében a védelmi miniszter újabb csökkentést jelentett be, ennek mértékét azonban még nem közölték.

9 Az F-35-ös program kapcsán készült hivatalos államigazgatási dokumentumokban (például képviselőházi, szenátusi jelentések) egyszer sem szerepel az, hogy az F-35-ösök a B-61-es töltetek hordozására képesek lesznek. Ennek okai közé sorolhatjuk, hogy az olasz politikum inkább a nukleáris fegyverek leszerelését támogató nyilatkozatokat tett/tesz.

10 Katonai szempontból a békeszerződés korlátozta a hadsereg létszámát és fegyverzetét. Olaszországnak fel kellett számolnia határerődjeit, haderejét a csendőrséggel együtt 250 ezer főben maximalizálták. A békeszerződés megtiltotta, hogy az olasz hadseregnek nehéztüzérsége, bombázó repülőgépei, atomfegyverei legyenek. Az olasz flottát a szövetségesek szétosztották egymás között. Lásd: Halmosy Dénes: Nemzetközi szerződések 1945-1982. A második világháború utáni korszak legfontosabb külpolitikai szerződései, Közgazdasági és Jogi Könyvkiadó, Budapest, 1982, 105-113. o.
} 
katasztrofális hatásait tovább marginalizálja Olaszországot. ${ }^{11}$ Ezt a véleményt a politikum is átvette, a bipoláris rendszerben a külpolitikai célok megfogalmazásánál következetesen tükröződött a nemzetközi státusz kompenzálásának igénye.

Ez a feltevés és az ellensúlyozási törekvések alapozták meg Olaszország katonai nukleáris politikáját a hidegháború alatt, amelynek így fö törekvése a kezdeti hátrányok csökkentése és az európai hatalmakkal való paritás elérése lett. Albert Wohlstetter amerikai szakértő Foreign Affairsben megjelent elemzése szerint az európai NATO-tagállamok négyféle nukleáris politikát folytathattak, az USA nyújtotta nukleáris garancia kihasználása mellett: 1. az atomfegyverek teljes elutasítása (ez a hidegháborús viszonyok között egyetlen nyugat-európai állam számára sem volt felvállalható a Szovjetuniótól való félelem miatt); 2. nemzeti nukleáris képesség kialakítása (ehhez a háború utáni Olaszország nem volt megfelelő állapotban); 3. közös ellenőrzés alatt álló, nyugat-európai nukleáris erő létrehozása; 4. USA-ra való hagyatkozás. ${ }^{12}$

Az Olasz Köztársaság számára a katonai felhasználású nukleáris technológiához való hozzájutást két körülmény megváltozása tette lehetővé: egyrészt 1951-ben a második világháborút lezáró békeszerződésből a NATO-szövetségesekkel való megállapodás alapján, a Szovjetunió tiltakozása ellenére eltörölték a katonai klauzulákat, ${ }^{13}$ így az újrafegyverkezés előtt nem álltak további korlátok, új lehetőségek nyíltak Olaszország előtt a müködőképességének határán levő fegyveres erőinek fejlesztésére, valamint a NATO által garantált biztonsághoz való hozzájárulásra. A másik fontos momentum az Eisenhower-adminisztráció azon döntése volt, amellyel a NATO biztonságának központi elemévé tette a nukleáris fegyvereket és azok megosztását még az 1957-es szovjet rakétatechnológiai áttörés előtt, ami így a transzatlanti kapcsolatok kritikus pontja lett a következő évtizedben. Olaszországot talán a többi európai országnál is érzékenyebben érintette a NATO nukleáris szövetséggé válása, hiszen a köztársaság 1947-es megszületése óta az olasz külpolitika középpontjában az ország nemzetközi rangjának és súlyának növelése állt, a kétszintű NATO kialakulásával pedig Olaszország kimaradt a belső körből, ami a második világháborús vereségének ellensúlyozását nem segítette.

Az ötvenes évek nukleáris forradalma után az olasz nukleáris stratégia a transzatlanti együttműködés erősítésén alapult: bár a kormány tett néhány lépést nemzeti szinten is (lásd a kutatóintézetek felállítását), de a nukleáris technológiához való hozzájutás fö forrását és a bárminemü nukleáris hatalmi státusz elérését a transzatlanti kapcsolatok erősítése jelentette. ${ }^{14}$ Mindaddig, amíg a transzatlanti biztonsággal kapcsolatos viták középpontjában a nukleáris technológiák megosztása állt, Olaszország az előbbi, kooperáción alapuló

11 A nukleáris kutatások terén a civil és a katonai szféra egyetértése jó ideig ebben merült ki. Az eredeti tervek szerint egy civil-katonai vegyes bizottság és kutatóintézet létrehozását tervezték az olasz kormányok, amely a nukleáris energia civil és katonai felhasználását egyaránt kutatta volna, a testület ellenőrzéséről és lehatárolt feladatköréről azonban nem tudtak megegyezni. 1950-51-re történt meg a teljes szakadás, így két, egymástól teljesen elkülönült kutatói struktúra jött létre: 1952-ben a Nukleáris Kutatások Nemzeti Bizottsága (Comitato Nazionale per le Ricerche Nucleari-CNRN), 1955ben pedig a Nukleáris Energia Katonai Alkalmazása Központ (Centro Applicazioni Militarti Energia Nucleare - CA$M E N)$ létrehozásával a nukleáris energia civil és katonai kutatása teljesen elvált egymástól. Nutı: i. m., 170.

12 Albert Wohlstetter: Nuclear Sharing: Nato and the N+1 Country, [online], 1961. 04. Forrás: ForeignAffairs.com [2019. 02. 23.]

13 Norman Kogan: The Revision of Italian Peace Treaty, Indiana Law Journal, 28. évf., 1953/3, 353-355. o.

14 Nuti: i. m., 172. 
álláspontot képviselte, így aktívan lobbizott a NATO-n belül az atomfegyverek közös ellenőrzéséért, amelynek megvalósulása nemzetközi rangjához képest nagyobb beleszólást engedett volna az országnak a nukleáris arzenál bevetésével kapcsolatos döntésekbe. A nukleáris fegyverek Olaszország területén történő állomásoztatása az olasz diplomácia számára nukleáris „klubtagság” mellett a NATO politikájára gyakorolt nagyobb befolyással volt egyenértékü. ${ }^{15} \mathrm{Az}$ ötvenes évek végén a kontinentális Európában Olaszország volt az egyik olyan állam, ahonnan a Szovjetunió területét mélységben lehetett volna nukleáris csapással sújtani, így figyelembe véve az ország akkori gazdasági állapotát és a háború utáni meggyengült érdekérvényesítő képességét, az olasz kormány számára a nukleáris rakéták állomásoztatása volt talán a legerősebb politikai ütőkártya saját nemzetközi súlyának növelésére. Az USA-ra való támaszkodás folyamatosságát az úgynevezett FIG (FrancoItalo-German) projekt gyengítette meg egy ideig, amely kifejezetten európai atomfegyver létrehozását célozta volna. Olaszország a háromoldalú tárgyalásokról az USA-val is folyamatosan egyeztetett, a projektet föként arra használták, hogy több nyomást helyezzenek az USA-ra az atomfegyver megosztására. ${ }^{16}$

John F. Kennedy elnökké választásával az USA nukleáris politikájában változások következtek be, amelyek közvetlen hatást gyakoroltak Olaszországra. Egyrészt, ahogy az USA távolodott a nukleáris megosztás stratégiájától, ${ }^{17}$ úgy távolodott Olaszország a saját értelmezése szerinti nukleáris klubtagságtól. Másrészt az USA azon döntése, hogy a nukleáris megosztásról lemondjon a Szovjetunióval kötendő non-proliferációs szerződésért cserébe, a transzatlanti együttműködésre alapozott olasz nukleáris politika kudarcát jelentette. Ez heves reakciókat váltott ki az olasz diplomáciából, így ugyanis a nukleáris technológia nemzeti önerőből való megszerzése maradt az egyetlen út a hőn áhított atomhatalmi státusz eléréséhez. Épp ezért az olasz kormány határozottan ellenezte a nukleáris fegyverek elterjedésének megakadályozásáról szóló szerződés (Treaty on the Non-Proliferation of Nuclear Weapons, NPT) megkötését, amelynek a Szovjetunióval már egyeztetett tervezetét az USA

15 A nukleáris rakéták befogadásának fontosságát jelzi, hogy az ötvenes évek végén az olasz diplomácia egyes tagjai úgy gondolták, hogy ezzel Olaszország közelebb van a nukleáris klubtagsághoz, mint Franciaország, pusztán azért, mert nem gyártja a nukleáris rakétafejeket, hanem a területén állomásoztatja azokat. NuTi: i. m., 174.

161954 óta több javaslat is született egy európai nukleáris erő felállításáról, amelynek alapját a francia-német tudományos és pénzügyi együttműködés képezte volna. A kezdeti szakaszban Olaszország részvételével még nem számoltak, a FIG projektben való részvételét az indokolta, hogy ekkor még egy kizárólagos francia-német együttmüködés nukleáris kérdésekben elképzelhetetlen volt. A francia, német és olasz védelmi miniszterek 1957 novemberében egy olyan titkos jegyzőkönyvet írtak alá, amelyben kifejezték a nemzeteikből álló, európai fegyverkezési csoport létrehozására vonatkozó szándékukat, amely három szektort ölelt volna fel: atomenergia, elektronika, repüléstechnika. Azonban már 1958-ban, nagyrészt francia nyomásra a háromoldalú nukleáris együttműködést felfüggesztették, mert De Gaulle szerint az atomfegyvereket soha nem szabad megosztani másokkal, ezzel az amúgy is gyenge lábakon álló, európai nukleáris elrettentő erő teremtését célzó projekt befejeződött.

Lásd: Massimiliano MoretTi: A never ending story: the Italian contribution to FIG. In: Elisabetta BINI - Igor LoNDERo (eds.): Nuclear Italy - An International History of Italian Nuclear Policies during the Cold War, EUT, Edizioni Universitá di Trieste, Trieszt, 2017, 105-119. o.

17 A rugalmas reagálás elképzelés szintjén az Egyesült Államokban már az 1950-es években megjelent, Kennedy elnökké iktatása után pedig uralkodó doktrínává vált. Az Egyesült Államok már 1961-ben módosította stratégiai dokumentumait, a NATO-ban a váltás viszont csak 1968-ban következett be. A késlekedésnek részben a NATO-n belül kialakult feszültség volt az oka, ugyanis egyes európai tagállamok, különösen Franciaország rossz néven vette a rugalmassággal együtt járó „korlátozott (nukleáris) háború” elképzelését, Olaszországhoz hasonlóan Franciaország is úgy értékelte a stratégiai váltást, hogy az Egyesült Államok lazított Európa felé tett kötelezettségein. 
1966 decemberében osztotta meg néhány NATO-tagállam (Kanada, Egyesült Királyság, Franciaország, Német Szövetségi Köztársaság, Olaszország) külügyminisztereivel. ${ }^{18}$

Az olasz kormány amellett, hogy a tervezet jelentős felülvizsgálatát javasolta, tárgyalásokat kezdett az NPT-t leginkább ellenző másik nyugat-európai állammal, a Német Szövetségi Köztársasággal, az NPT megakadályozására irányuló erőfeszítéseik koordinálása céljából. Ugyanakkor a német-olasz tengely kialakulása a második világháború közelsége miatt még rossz emlékeket idézett a nemzetközi közösségben, így közös, nyílt és határozott olasz-német fellépésről nem beszélhetünk. ${ }^{19}$ Az NSZK-hoz hasonlóan Olaszország is azt az álláspontot képviselte, hogy a szerződés a nukleáris és nem nukleáris államok felosztásával bebetonozná a nyugat-európai államok közötti különbségeket, akadályozva az európai integráció mélyülését, ami a föderalista elképzelések végét jelentené, tehát egy korlátozott időtartamú szerződés megkötésében volt érdekelt, ami lejárta esetén lehetőséget adott volna a státuszok újratárgyalására. A nukleáris államok körének meghatározása egyben azt is jelentette, hogy szerződésbe foglalták Olaszország - és Németország - katonai alsóbbrendüségét a nukleáris hatalom Franciaországhoz képest, ami különösen fájó pont volt az olasz vezetésnek. Az Olaszország által benyújtott módosító indítványok ezért az NPT Olaszország nukleáris státuszára gyakorolt negatív hatásainak csökkentését célozták. Az NPT 1969. januári aláírásakor ${ }^{20}$ Olaszország egyoldalú szóbeli jegyzéket adott át az Egyesült Államok, a Szovjetunió és Nagy-Britannia kormányainak - tehát Franciaországnak nem -, amelyben kifejezte a szerződéssel kapcsolatos fenntartásait. Ezek szerint a szerződés nem veszélyeztetheti tovább az európai integrációt és a politikai unió elérésének végső célját (úgynevezett európai klauzula); kompatibilisnek kell lennie a meglévő biztonsági kötelezettségvállalásokkal (például NATO); a szerződés aláírásával fennmarad a lehetőség nem fegyvercélú nukleáris töltet (peaceful explosive devices other than nuclear weapon) fejlesztésére; valamint a jövőben a szerződésben foglalt, öt elismert nukleáris hatalomhoz újabb állam nem csatlakozhat. ${ }^{21}$ Mai viszonyok között a legfontosabb az utolsó kiegészítés, amely lényegében egy formális tiltakozás az ellen, hogy bármely más állam - például Izrael, India, Pakisztán stb. - elismert nukleáris állami státuszért folyamodjon a jövőben.

A tanulmány elején említett nukleáris taktikai fegyverek olasz állam területén való állomásoztatása felveti a kérdést, hogy a gyakorlat összeegyeztethető-e az NPT-vel. A szerződés szerint az USA az elismert nukleáris hatalmak közé tartozik, joga van nukleáris fegyvereket birtokolni, azonban sem közvetlenül, sem közvetve senkinek nem adhat át nukleáris fegyvereket, illetve nem engedheti át az ellenőrzést felettük; a nem nukleáris hatalom Olaszország pedig nem állíthat elő és nem veheti át az ellenőrzést nukleáris fegyverek

18 William Alberque: The NPT and the origins of NATO's nucelar sharing arrangements, Proliferation Papers, 2017/57, 1-58. o.

19 Cesare MERLINI: A concise history of nuclear Italy, The International Spectator: Italian Journal of International Affairs, 23. évf. 1988/3, 135-152. o.

20 Az NPT ratifikációjánál a korábban bemutatott stratégia ismét megvalósult: a szerződésben foglaltakkal kapcsolatos ellenérzések miatt a parlament csak akkor ratifikálta az NPT-t, amikor már úgy tűnt, hogy a ratifikáció hiányában az olasz delegáció nem vehet rész a szerződés első öt évének felülvizsgálatát célzó nemzetközi konferencián (1975. május), ahol viszont a nagyhatalmak részt vettek. Végül 1975 áprilisában ratifikálták a szerződést, a genfi felülvizsgálati konferencián pedig az olasz delegáció volt az egyik legnépesebb. Uo., 145.

21 Uo., 144. 
felett (szerződés 1., illetve 2. cikkelye). ${ }^{22}$ Ezen ellentmondás feloldása érdekében kétkulcsos rendszert alkalmaznak, amely alapján az olasz bázisokon állomásoztatott nukleáris fegyverek az Egyesült Államok birtokában és szoros ellenőrzése alatt állnak, bevetésükről csak az USA dönt, ehhez azonban a területi államnak, azaz jelen esetben Olaszországnak is hozzá kell járulnia. Így formálisan Olaszország semmilyen ellenőrzést nem gyakorol az amerikai nukleáris robbanófejek felett, jelenlétük tehát nem ütközik az NPT által elöírtakba, a szerződésben foglaltak betartását ellenőrző Nemzetközi Atomenergia Bizottság sem emelt ellene kifogást.

Az NPT aláírása nemcsak az olasz nukleáris politika felülvizsgálatához vezetett, hanem az Egyesült Államokkal való kapcsolatok átalakulásához is. Az NPT-vel kapcsolatos ellenérzések meghatározták Olaszország álláspontját az új generációs, közepes hatótávolságú, amerikai nukleáris fegyverek telepítéséről folytatott vitában, amelyek Európába telepítésének terve az olasz vezetés számára újabb lehetőséget jelentett az általuk nemzetközi döntéshozói körként értelmezett országok közé való visszakerülésre, a kizártság kompenzálása miatt határozottan támogatta az új fegyverek telepítését.

A döntésekböl kizártság érzését növelte, hogy Olaszország nem kapott meghívást az 1979. januári, guadeloupei konferenciára, ahol a részt vevő nagyhatalmak új fegyverrendszerek telepítését kérték a NATO-tól, a távolmaradás rendkívül érzékenyen érintette az olasz diplomáciát. A konferencia bejelentése után a washingtoni olasz nagykövet tiltakozását fejezte ki Olaszország meg nem hívása miatt, a fennmaradt diplomáciai források szerint azonban Zbigniew Brzezinski nemzetbiztonsági tanácsadó közölte vele, hogy egy bizonyos szintü belpolitikai stabilitás szükséges ahhoz, hogy ilyen szintű nemzetközi tárgyalásokra meghívást kapjon egy ország. ${ }^{23}$

$\mathrm{Az}$ eurorakéták telepítésének erőteljes támogatásának és a kis hidegháború alatti újrafegyverkezési folyamatban játszott aktív szerepnek ${ }^{24}$ a célja a hetvenes évek gazdasági problémái, a sorozatos baloldali terrortámadások, a politikai instabilitás miatt törékeny és megbízhatatlan partner képének helyreállítása volt. Az eurorakéták telepítésének támogatása mögött ugyanaz a logika bújik meg, mint az ötvenes években: a NATO nukleáris arzenáljának modernizálását - és a kisebb szövetségesek háttérbe szorulását - kihasználva Olaszország a Szovjetunióval globális kérdésekben tárgyalásokat folytató nyugati hatalmak körébe akart bekerülni, növelve nemzetközi elismertségét és befolyását. Ezzel párhuzamosan az új rakéták telepítésével Olaszország lehetőséget próbált teremteni az NPT ratifikálásával életbe lépett szabályok újratárgyalására, hátha ily módon kimozdulhat a nem nukleáris állam státuszából.

A fenti stratégiai gondolkodás alapján kevéssé meglepő, hogy Olaszország volt az egyetlen nyugat-európai állam, amely ténylegesen müködő kétkulcsos megállapodást szeretett volna kötni a területén állomásoztatott nukleáris fegyverek ellenőrzéséről..$^{25}$ Ennek keretében a nukleáris fegyverek tényleges használatához az olasz kormány politikai jóváhagyása

22 1970. évi 12. törvényerejü rendelet, [online]. Forrás: net.jogtar.hu [2019. 01. 23.]

23 Olav NJølstad (ed.): The Last Decade of the Cold War: From Conflict Escalation to Conflict Transformation, Frank Cass, London - New 2005, 286. o.

24 Antonio Ciarrapico: Rapporti Est-Ovest 1977-79. La vicenda degli Euromissili, Rivista di Studi Politici Internazionali, 69. évf., 2002/3, 363-380. o.

25 Nuti: i. m., 177. 
mellett két indítókulcs alkalmazására lett volna szükség, az egyik egy olasz katona által került volna behelyezésre, míg a másik az amerikaiaknál lett volna. A cél az volt, hogy egy nukleáris háború esetén az ország aktív szerepet játszhasson a kulcsfontosságú döntések meghozatalában, ne kelljen passzívan elfogadnia más tagállamok döntéseit. Ez a mechanizmus azonban egy 1962-ben aláírt olasz-amerikai megállapodás alapján csak a Jupiter rakéták esetében müködött körülbelül egy évig (a Jupitereket 1960-1963 között állomásoztatták Olaszországban), minden más esetben Olaszország csak egy „virtuális” kulccsal rendelkezett, ${ }^{26}$ a fegyverek esetleges bevetése esetén valódi befolyása csak az Egyesült Államok jóindulatán múlt volna, az USA azonban egy azonnali döntést kívánó válsághelyzetben kis valószínüséggel kérte volna a folyamatos kormányválsággal küzdő olasz vezetés jóváhagyását.

A hidegháború időszaka alatt a nukleáris politikával elérni kívánt külpolitikai célok mellett a belpolitikai célok is egyértelmüek voltak. A bipoláris környezet erőteljesen meghatározta a széttagolt, kormányzatilag instabil olasz belpolitikát, ${ }^{27}$ hiszen a bipolaritáshoz igazodott a pártok közti versengés fö törésvonala: az átlagosan 30\%-os támogatottsággal rendelkező Olasz Kommunista Párt (Partito Communista Italiano, PCI) koalícióképtelen volt, a tőle jobbra levő pártok azonban elméletileg részesedhettek a hatalomból. A teljes hidegháború ideje alatt minden nukleáris vonatkozású kérdésben egy szűk, atlantista beállítottságú olasz elit döntött, akik a technikai és politikai természetü vitákat is szük keretek között tartották, legtöbb esetben a nyilvánosság tájékoztatása nélkül, az ellenzéki helyzetben levő, de nagy támogatottságot élvező Kommunista Párt általi mozgósítás elkerülése érdekében.

A Kommunista Párthoz köthető leginkább az antinukleáris tüntetések és mozgalmak támogatása, ami több következménnyel is járt. Egyrészről az, hogy éppen a kommunisták tüzték zászlajukra a tiltakozó mozgalmak támogatását, a politikai rendszer sajátosságai miatt valószínúleg megakadályozta, hogy Olaszországban is az észak-európai mozgalmakhoz hasonló, antinukleáris tömegmozgalmak alakuljanak ki. Így ezek a mozgalmak még a legnagyobb támogatottságuk idején sem késztették meghátrálásra a kormányt. ${ }^{28}$ Másrészről, paradox módon a nukleáris technológiáknak épp a kommunisták általi ellenzése volt az, ami a gyakran cserélődő, de külpolitikájukban hangsúlyosan nyugati orientációjú kormányokat még akkor is elfogadó álláspontra kényszerítette, ha egyébként nem feltétlenül lettek volna meggyőződve az adott atomfegyver olaszországi állomásoztatásának célszerüségéről. A kommunisták általi nyílt tiltakozás tehát a kormányt a nyugati orientáció kihangsúlyozására késztette, a taktikai nukleáris fegyverek állomásoztatásának kérdését gyakorlatilag a „kelet” és a „nyugat” közti választásra egyszerüsítve le.

Annak ellenére, hogy a hatvanas évektől, a gazdasági csoda éveitől kezdve Olaszország technikai, tudományos és gazdasági szempontból is képes lett volna saját, nemzeti nukleáris programjának beindítására, erre valódi szándék sosem mutatkozott. Az amerikai

26 FORAdORI: Reluctant disarmer... i.m.

27 Bővebben lásd: LÁszLó Réka: Kormányzati instabilitás és a politikai rendszer stabilitása. A pártokrácia hatása az olasz politikai rendszerre. Politikatudományi Szemle, 15. évf., 2006/1, 69-92. o.; és Molnár Anna: Olaszország története a második köztársaság idején. Áron Kiadó, Budapest, 2011.

28 Renato Moro: Against the Euromissiles: Anti-nuclear Movements in 1980s Italy (1979-1984). In: BINI-LONDERO: i. m., 199-211. 
nukleáris fegyverek befogadása jelentette Olaszország számára az egyetlen elfogadható utat a nukleáris fegyverek birtoklásához és az ehhez társuló politikai státuszhoz. Az olasz haderő az egyik első volt Nyugat-Európában, amelyik egy olyan taktikai doktrínát dolgozott ki, amely nukleáris fegyverek elterjedése jelentette változásokat elismerte, és az operatív tervezés során a taktikai nukleáris fegyvereknek fontos szerepet szánt. ${ }^{29}$

\section{A nukleáris fegyverek állomásoztatásának aktuális kérdései}

A hidegháború végén, a Szovjetunió felbomlásával megszünt az ősellenséggel való szembenézés kényszere, így eltünt a taktikai nukleáris fegyverek európai telepítésének eredeti indoka. A NATO csökkentette a nukleáris fegyverekre való támaszkodását védelmi stratégiájában, jelentősen csökkentve a nukleáris fegyvereinek számát is, ahogy ez a szövetség 1999-es Stratégia Koncepciójában is megjelent. ${ }^{30}$

A nemzetközi környezet változásával a nukleáris taktikai fegyverek Olaszországban való állomásoztatásának eredeti indoka lényegében eltünt, hiszen egyrészről az ország biztonságát a kilencvenes évek eleje óta nem fenyegeti egy olyan egyértelmü és körülírható kihívás, ami ilyen fegyverek jelenlétét szükségessé és indokolttá tenné, másrészről a technikai fejlődés meghaladta a nukleáris fegyverek bevetésének a szükségét. Jelenleg bárminemű válság kezelésére számos jobb alternatíva létezik, mint a modern légvédelmi eszközök által támadható, elhárítható repülőgépek által hordozott nukleáris gravitációs bombák bevetése. Nehéz elképzelni olyan helyzetet, amelyben minden NATO-tagállam egyetért a nukleáris fegyverek alkalmazásáról. A hagyományos és a nem hagyományos alternatívák müveletileg és politikailag is elfogadhatóbbak a nukleáris fegyvereknél. A technikai és technológiai fejlödés következtében a hagyományos fegyverek napjainkra olyan pontosak és hatékonyak lettek, hogy a szövetség biztonságát érintő, szinte minden modern fenyegetésre adekvát választ tudnak adni. Még a legrosszabb esetben is, amennyiben sor kerülne a nukleáris fegyverek tényleges bevetésére, nehéz elképzelni, hogy a NATO - és azon belül fóként az Egyesült Államok - az Európában állomásoztatott nukleáris fegyverek alkalmazása mellett döntene, hiszen gyorsabb, pontosabb, nagyobb hatótávolságú amerikai stratégiai nukleáris fegyverek vethetők be tengerről vagy amerikai szárazföldi területekről.

Az új világrendben a nukleáris töltetek állomásoztatása jelentette külpolitikai „érték” is csökkent, amely korábban az ország nemzetközi megítélését, a NATO-n belüli pozícióját és a mindenkori olasz kormány számára kiemelten kezelt, Egyesült Államokkal való privilegizált kapcsolatokat volt hivatott javítani. Összességében megalapozatlannak bizonyult az a hidegháborús elképzelés, hogy a nukleáris fegyverek befogadásával az ország könnyedén nagyhatalmi státuszba kerül anélkül, hogy költséges és hosszas strukturális reformokat hajtana végre politikai és gazdasági téren is, amellyel koherens és hiteles kül- és biztonságpolitika kialakítására lett volna lehetőség, hiszen az amerikai nukleáris fegyverek befogadása az ország nemzetközi reputációjára kevés hatást gyakorolt, valamint nemzetközi befolyását sem növelte. Olaszországnak nem sikerült a „belső körbe” bekerülni

\footnotetext{
29 Paolo ForAdori: Tactical Nuclear Weapons in Italy: Striking a Balance between Disarmament Aspirations and Alliance Obligations, The Nonproliferation Review, 19. évf., 2012/1, 13-29. o.

30 NATO Strategic Concept, [online], 1999. 04. 24. Forrás: Nato.int [2019. 01. 23.]
} 
sem a NATO-ban (így a „Quad”-ként ismertté vált négyeshez ${ }^{31}$ sem csatlakozott), sem általánosságban a nemzetközi porondon. Ez már a hidegháború alatt is megmutatkozott, azonban az új világrendben, amikor az ország földrajzi elhelyezkedése már nem stratégiai fontosságú a keleti-nyugati szembenállás szempontjából, ${ }^{32}$ még nyilvánvalóbbá vált.

A külső környezet változásaival párhuzamosan a hidegháború alatt meglehetősen passzív olasz biztonságpolitika is lényegi változásokon ment át. A hidegháború statikusabb, egyirányú fenyegetettséget érzékelö, hagyományos ötödik cikkelyes, területvédelmi feladatok helyett egy rugalmasabb biztonság és védelempolitika kialakításával növekedtek az olasz erőkivetítési képességek, a haderő nemzetközi missziók keretein belül távoli válságövezetekben is bevethetővé vált, ${ }^{33}$ Olaszország a biztonság fogyasztójából (security consumer) a biztonság elöállítója (security provider) lett. A külföldi válságkezelési és békefenntartási feladatok során viszont a taktikai nukleáris fegyverek nem alkalmazhatók. Az olasz politikum elfogadta, hogy a 21. században az ország nemzetközi súlyát nem a taktikai nukleáris fegyverek befogadása jelenti, hanem a nemzetközi válságok kezelésében való aktív részvétel. Elfogadottá vált az a nézet is, amely szerint a NATO és az EU nemzetközi biztonságban betöltött szerepének és a szervezetek identitásának változásával a kollektív biztonsághoz való hozzájárulás, azaz a nemzetközi missziókban való részvétel a saját biztonság feltétele is lett; nem véletlen, hogy az utóbbi évtizedekben Olaszország számos, saját nemzeti érdeke szempontjából is fontos, nemzetközi misszióban vett részt.

Belpolitikai szempontból a kétpólusú rendszer összeomlása után az Olasz Kommunista Párt ellenzékben tartásának szükségessége meghaladottá vált, hiszen a PCI egy modern, koalícióképes, elfogadott szociáldemokrata párttá vált, nem követelte többé az ország külpolitikai orientációjának átalakítását. Sőt, a szerbiai NATO-beavatkozásban való részvételről már egy olyan olasz kormány döntött, amelynek miniszterelnöke, Massimo D’Alema korábban a PCI tagja volt. ${ }^{34}$

Minden valószínűség szerint az is közrejátszik abban, hogy a NATO-n belül Olaszország mindig is lojális, de passzív tagállam volt, aki az USA döntéseit ritkán kérdőjelezte meg, így próbálta elkerülni a mindenkori vezetés, hogy a nemzetközi politikai kérdésekkel kapcsolatos vita és állásfoglalás az ideológiailag egyébként is széttöredezett olasz belpolitika újabb törésvonalává váljon. Napjainkra a belpolitikai dimenzió szinte eltünt, a nukleáris fegyverekkel kapcsolatos vita amellett, hogy a politikai diskurzus perifériájára került, általánosságban depolitizált, ezt mutatja az is, hogy a Tornadók helyettesítésére szánt F-35-ös vadászgépek beszerzéséről folytatott társadalmi és politikai vitában nem is merült fel az új vadászgépek kettős felhasználást lehetővé tévő természete, a középpontban inkább a projekttel kapcsolatos kiadások álltak.

31 USA, Egyesült Királyság, Németország, Franciaország.

32 Vitathatatlan, hogy Olaszország földrajzi elhelyezkedése továbbra is alapvető fontosságú az Európai Unió biztonsága szempontjából, hiszen az észak-afrikai térségből érkező illegális migrációs hullámok elsődleges célpontja, de a nukleáris fegyverek állomásoztatása szempontjából a földrajzi pozíciójából fakadó értékét elveszítette.

33 FORAdoRI: Reluctant disarmer... i. m., 34.

34 Governi italiani dal 1943 ad oggi: Governo D’Alema, [online]. Forrás: Governo.it [2019. 01. 23.] 


\section{Leszereléssel kapcsolatos politikai állásfoglalás}

Annak ellenére, hogy a nukleáris fegyverek befogadásának eredeti indokai eltüntek, Olaszország mégsem tesz aktív lépéseket a leszerelés érdekében. Az olasz hatóságok hivatalosan a nukleáris fegyverek leszerelése mellett foglalnak állást, tényleges lépések azonban csak a NATO-tagállamok egységes állásfoglalása esetén elképzelhetők. Amíg tehát bármelyik NATO-tagállam - mint például a balti vagy a kelet-közép-európai tagállamok - biztonsági értéket tulajdonítanak az Európában állomásoztatott nukleáris fegyvereknek, a szövetség kohéziójának megörzése érdekében Olaszország kész a teljes kivonással kapcsolatos döntések lelassítására és elhalasztására, hiszen külpolitikájában hagyományosan a multilaterális döntések bárminemü unilaterális lépéshez képest előnyt élveznek. Bár a 2018 tavaszán hatalomra került Conte-kormány külpolitikája egyes elemeiben konfrontatívabb, sok esetben a Lega-M5S koalíció is az elődjeinek politikáját követi.

A NATO továbbra is biztos utat jelent az Egyesült Államokkal való privilegizált kapcsolatokhoz, a közelmúltig a stabilitás garantálója volt olyan területeken, amelyek Olaszország biztonságának fenntartása szempontjából elsődlegesek, mint például a Balkán. A NATO az Oroszországgal és a Törökországgal való kapcsolatok alakításában is erősebb tárgyalópozíciót biztosít Olaszország számára, továbbá a katonai képességek fejlesztéséhez is hozzájárul. Az olasz hadiipar számára a NATO-tagállamok piacain való jelenlét ${ }^{35}$ kiegyenlíti az olaszországi kereslet és kínálat közötti egyensúlytalanságot, ${ }^{36}$ így Olaszország biztonsága szempontjából mind stratégiai, mind politikai és gazdasági szempontból továbbra is releváns szerepet tölt be. Ezen megfontolások alapján Olaszországnak nem érdeke, hogy a kontinensen állomásoztatott nukleáris taktikai fegyverek kapcsán olyan álláspontot fogadjon el, amely a tagállamok közti megosztottsághoz vezetve gyengítené a Szövetség kohézióját.

Róma retorikailag határozottan kiáll a nukleáris leszerelés mellett, a parlament 2009ben, 2010-ben és 2012-ben is a teljes politikai spektrum által támogatott javaslatot fogadott el, felszólítva a kormányt, hogy minden nemzetközi fórumon aktívan járuljon hozzá a nukleáris fegyverek leszereléséhez, és a non-proliferációs célok megvalósításához. A retorikai támogatás ellenére azonban az olasz kormányok konkrét kezdeményezéssel nem álltak elő, így továbbra is az amerikai preferenciák megvalósítása várható a már-már hagyományosnak mondható olasz külpolitikai gyakorlat szerint, hiszen a Washingtonnal való kapcsolatok primátusában a politikai spektrum összes pártja egyetért.

A nukleáris fegyverek állomásoztatása mellett szóló eredeti politikai és katonai megfontolások eltűnése, illetve a leszerelés retorikai támogatása ellenére az olasz kormány nem csatlakozott a három NATO-tagállamhoz - Németországhoz, Belgiumhoz és Hollandiához -, akik inkább a területükön állomásoztatott nukleáris fegyverek leszerelése mellett foglalnak állást kb. 2009-2010-től kezdve. ${ }^{37}$ Amennyiben azonban a fenti országok közös álláspontra jutnak a leszerelés kapcsán, Olaszország várhatóan nem fog

\footnotetext{
35 Az olyan hadiipari vállalatok, mint a Finmeccanica vagy a Leonardo túl nagyok ahhoz, hogy pusztán az olasz állami megrendelésekből fenn tudják tartani magukat, ehhez nagyobb piacokhoz való hozzáférésre van szükségük, ezt elsősorban az európai NATO-tagállamok, másodsorban pedig az Egyesült Államok piacán keresztül valósítják meg.

36 Ricardo Alcaro: The Italian Government and NATO's New Strategic Concept, [online], 2010. 06. Forrás: Iai.it [2019. 01. 30.]

37 Laura Spagnuolo: Italy’s Tactical Nuclear Weapons, [online], 2011. 05. 20. Forrás: Basicint.org [2019. 02. 02.]
} 
ragaszkodni ahhoz, hogy a nukleáris fegyverek az ország területén maradjanak. Hiszen olyan országok akaratával kerülne így szembe - például Németországéval -, amelyek státuszát régóta szeretné elérni. A többi NATO-tagállam közös akaratával való szembehelyezkedés az olasz külpolitika számára oly fontos nemzetközi rangot veszélyeztetné, elszigetelődést kockáztatna.

A német-belga-holland leszerelési kezdeményezések óta eltelt időszakban az olasz kormányokat más-más prioritások vezérelték, a nukleáris fegyverek leszerelésének kérdése nem szerepelt a politikai agendán. Silvio Berlusconi negyedik kormánya (2008-2011) inkább a személyes kapcsolatokra épülő, bilaterális külpolitikát favorizálta az amerikai kapcsolatok kihangsúlyozásával, amellyel párhuzamosan a multilateralizmus háttérbe szorult. Ez a nyílt atlanti orientáció nem tette lehetővé a Berlusconi-kormánynak a leszerelést támogató országokkal - élükön Németországgal - közös állásfoglalást az Egyesült Államok ellenében a nukleáris fegyverek kapcsán. A Berlusconi bukását követően hatalomra került, szakértői Monti-kormánynak (2011-2013) sem ereje, sem mandátuma, sem megfelelő vezetője nem volt ahhoz, hogy egy olyan bonyolult döntéseket igénylö témával foglalkozzon, amely egyrészt nem prioritás - ez már a gazdasági és a migrációs válság hatásait csillapítani kívánó kettős válságkezelési mechanizmus időszaka -, másrészt pedig a koalíción belül vitákra adhatott volna okot. Ugyanez jellemzi a nagykoalíciós Letta-kormány, majd a Renzikormány idejét, sőt a Renzi-kormány 2016. október 27-én az ENSZ-közgyülés bizottsági ülésén az Egyesült Államokhoz hasonlóan nemmel szavazott a nukleáris fegyverek tilalmáról szóló szerződés (Treaty on the Prohibition of Nuclear Weapons) tárgyalásainak 2017-es megindítását magában foglaló határozatra. Bár a közgyülési szavazáson, 2016. december 23-án a Gentiloni-kormány igennel szavazott a tagállamok többségével együtt, ez nem jelentette az olasz álláspont megváltozását, a kormány szerint csak „technikai hiba” volt. ${ }^{38}$

A 2018 tavaszán kormányra kerülö Ötcsillagos Mozgalom-Liga koalícióban a koalíciós pártok eltérő álláspontot képviselnek a nukleáris fegyverek kapcsán: az Ötcsillagos Mozgalom a leszerelés végrehajtásával nukleárisfegyver-mentes övezetté szeretné tenni a Mediterráneum régióját, míg a Liga inkább az Egyesült Államokkal való, privilegizált bilaterális kapcsolatokat hangsúlyozza, amibe jelenleg a leszerelés kérdése nem fér bele. ${ }^{39}$ Ennek következtében ezek a kérdések háttérbe szorulnak, hiszen ennél jóval sürgetőbb témákban is véleménykülönbség van a kormánypártok között, így a törékeny kormánykoalíció fennmaradása érdekében ezzel a témával nem foglalkoznak.

Az olasz külpolitikai hagyományoknak megfelelve, a taktikai nukleáris fegyverek kivonásának kérdésében az Egyesült Államok akarata lesz a döntö, amennyiben a NATO-n belül sikerül egységes álláspontot elfogadtatnia. A fegyverek befogadása azonban már nem elsődleges a Washington iránti elköteleződés bizonyítására, az olasz-amerikai kapcsolatok kiegyensúlyozottnak és erősnek tekinthetők, az Egyesült Államok továbbra is igazodási pontja az olasz külpolitikának. Függetlenül attól, milyen kormánykoalíció van éppen hatalmon, a transzatlanti kapcsolatok nem gyengülnének meg, ha Európa teljes területéröl

38 Dinucci Manlio: Colpo di sonno nucleare, [online], 2017. 02. 28. Forrás: Peacelink.it [2018. 12. 11.]

39 Carlo Trezza: M5S/Lega: linee di politica estera parzialmente convergenti, [online], 2018. 10. 08. Forrás: Affariinternazionali.it [2019. 01.04.] 
kivonnák a taktikai nukleáris fegyvereket, egyoldalú olasz döntés meghozatala pedig nem reális alternatíva.

A nukleáris fegyverek leszerelésével kapcsolatos kérdések nem képezik a közbeszéd tárgyát, a politikai agenda prioritásai között tehát nem találjuk ott. A kül- és biztonságpolitikai prioritások középpontjában a kettős válságkezeléssel - egyrészt a pénzügyi-gazdasági, másrészt a migrációs és menekültkérdéssel - összefüggő kérdéseket találjuk, hiszen ezek a lakosság mindennapi élete mellett annak szubjektív biztonságpercepcióját is érezhetőbben érintik, mint az ország területén állomásoztatott nukleáris fegyverek, amelyekkel kapcsolatban a népesség nem is rendelkezik pontos információkkal. A nukleáris energia és technológia olasz lakosság általi elutasítása a csernobili katasztrófa után megnövekedett, a nukleáris kérdésekben tartott népszavazásokon a nukleáris technológiák civil célra történő felhasználását is elutasították, ${ }^{40}$ így feltételezhetö, hogy a katonai felhasználás elutasítottsága még nagyobb lenne, ha a kérdés a közbeszéd tárgyává válna.

A nukleáris fegyverek kapcsán a lakosság közvéleményét a kétezres évek közepéig nem kutatták, utána is csak néhány felmérés készült, amelyekből az állapítható meg, hogy a lakosság általánosságban inkább leszereléspárti. Az olasz közvélemény döntésekből való kizártságát mutatja, hogy egy 2006-ban készített felmérésen - ami tehát körülbelül fél évszázaddal azután készült, hogy az első amerikai atomfegyvereket Olaszország területére telepítették -, a lakosság 32,6\%-a nem tudta, hogy az ország területén nukleáris fegyverek vannak, és a válaszadók csupán 10,9\%-a tudta ezt biztosan. Miután elárulták a résztvevőknek, hogy független szakértők szerint vannak atomfegyverek az ország területén, a válaszadók több mint fele aggodalmát fejezte ki. Annak ellenére, hogy az öt, nukleáris fegyvereket befogadó európai ország válaszadói közül itt volt a legmagasabb azoknak a száma, akik nem tudtak az országba telepített atomfegyverekről, az atomfegyvermentes Európa elképzelésének Olaszországban volt a legtöbb támogatója, a megkérdezettek 71,5\%-a. ${ }^{41}$ Egy másik, 2007-es felmérésen a megkérdezettek 93\%-a azt mondta, hogy Olaszország célja az atomfegyverek csökkentése/felszámolása kell hogy legyen, 70\%-uk szerint az atomfegyverek NATO általi bevetése semmilyen körülmények között nem lenne elfogadható. ${ }^{42}$

A leszereléspárti lakosság mellett retorikai szinten az olasz politikum is a nukleáris fegyverek leszerelése mellett foglal állást, amely egyben az Olaszországban állomásoztatott atomfegyverek kivonását is jelentené. A konfliktuskerülö, multilaterális döntéseket minden téren az unilaterális döntések elé helyező olasz diplomácia azonban a fentiek ellenére sem fog egyoldalú lépéseket tenni a leszerelésre, a NATO-n belüli közös álláspont meg-

40 Először 1987-ben, a csernobili katasztrófa után nem sokkal tartottak referendumot, amely alapján az állam nem támogathatja a nukleáris energetikát, és korlátozták az atomenergetikai befektetéseket. A működő atomerőműveket bezárták, az így kieső energia pótlása súlyos gazdasági terheket rótt az országra. A fosszilis energiahordozók árának növekedésekor, 2008-ban a Berlusconi-kormány a nukleáris energia arányát 25\%-ra akarta növelni, amelyet 2030-ig fokozatosan vezettek volna be. Az ellenzék által kezdeményezett népszavazást 2011 júniusában tartották, nem sokkal a fukushimai baleset után, így a válaszadók 92\%-a elutasította a nukleáris program újrakezdését. Lásd: CsERHÁTi András: A leépítők - osztrák, olasz, német, svájci és japán atomenergia, Nukleon, 5. évf., 2012/115, 1-9. o.

${ }^{41}$ Stratcom: Nuclear Weapons in Europe: Survey Results in Five European Countries, [online], 2006. 05. 26. Forrás: Nonaumissilem51.org [2019. 02. 24.]

42 The Simons Foundation: Global Public Opinion on Nuclear Weapons, [online], 2007. Forrás: TheSimonsFoundation.ca [2018. 11.04.] 
születéséig, ez azonban a tagállamok eltérő biztonságfelfogása közötti különbségek miatt a közeljövőben nem valószínü.

\section{Konklúzió}

A második világháború után a nemzetközi rendszerben marginalizált, súlyát és hitelét vesztett Olaszország vezetése az amerikai nukleáris fegyverek befogadásában az amerikai és transzatlanti kapcsolatok javítása mellett az ország nemzetközi rangját növelő eszközt látta. Külpolitikailag a döntéshozó hatalmak körébe való bekerülés, belpolitikailag pedig a Nyugat-Európában legnagyobb támogatottsággal rendelkező Olasz Kommunista Párt ellenzékben tartása, ezzel az ország nyugati orientációjának megerősítése volt az a tényező, amely a nukleáris fegyverek befogadását indokolta évtizedeken keresztül. A hidegháború után a nemzetközi politikai rendszer változásával a belpolitikai ok megszünt, a PCI rendszer-kompatibilis, szociáldemokrata párttá alakult, a konkrét ellenségkép eltünésének és a nemzetközi környezet változásának következtében a transzatlanti elköteleződés fokmérőjét már nem az amerikai nukleáris fegyverek befogadása jelenti, így a külpolitikai megfontolások is megváltoztak.

A bipoláris és posztbipoláris világ biztonsági rendszerei között a különbség strukturális mélységü, az Olaszország biztonságát leginkább érintő fenyegetések és kihívások - regionális konfliktusok, terrorizmus, migráció - kezelésére a taktikai nukleáris fegyverek nem alkalmasak, katonai jelentőségük így gyakorlatilag megszünt. A biztonság fenntartásához ez a fegyvertípus nem járul hozzá, de nem is vesz el belőle.

A másik fél oldaláról tekintve, az Egyesült Államok globális stratégiai keretrendszerében Olaszország a második világháború vége óta privilegizált helyet foglalt el, amelyet az olaszországi amerikai jelenlét is tükröz a mai napig. Ehhez Olaszország földrajzi elhelyezkedése, USA irányába szinte kritika nélkül elkötelezett olasz politikum és diplomácia mellett az amerikai jelenlét olasz közvélemény általi általános elfogadottsága is hozzájárult.

A hidegháború végével Európa megszünt stratégiai hadszíntér lenni, Olaszország földrajzi elhelyezkedése is vesztett stratégiai jelentőségéből. Tekintettel azonban arra, hogy az Olasz Köztársaság megalakulása óta küzdött az európai hatalmakkal való egyensúly eléréséért, aminek a hidegháború hosszú évtizedei alatt a nukleáris fegyverek állomásoztatása integráns részét képezte, a történelem súlya ránehezedik az olasz döntéshozatalra: az ország természetszerüleg vonakodik kivonni a területéről azokat a fegyvereket, amelyek évtizedeken keresztül elsődleges szerepet játszottak a kül- és biztonságpolitikában.

Annak ellenére azonban, hogy a taktikai nukleáris fegyverek Olaszország területén történő állomásoztatásának eredeti belpolitikai, külpolitikai és katonai indoka is eltünt, értékük csökkent, az olasz vezetés retorikai szinten pedig elkötelezte magát a globális nukleáris leszerelés mellett, az ország ebben kezdeményező szerepet nem vállalt fel. Az olasz kormány számára - már-már - tradicionálisan az Európában állomásoztatott amerikai nukleáris fegyverek az Egyesült Államok európai elkötelezettsége mellett a NATO kohézióját jelképezik, amelynek megingatásához Olaszországnak nem kötődik érdeke, hiszen ez a szervezet az ország biztonságának elsődleges garantálója, és ennek meggyengüléseként értékelnék a nukleáris fegyverek kivonását. Olaszország olyan fokozatos, az összes 
tagállam egyetértésével született döntések végrehajtásában érdekelt a kohézió megtartása érdekében, amelyek az összes tagállam biztonságérzetét fenntartanák, tudva, hogy ezekben lényegi különbségek tapasztalhatók, ahogy ez látszik a leszerelést támogató országok (például Németország, Belgium, Hollandia) és a balti, kelet-közép-európai államok álláspontja esetében is. A közös álláspont - közeljövőben nem várható - eléréséig Olaszország kész a leszerelés kérdését elhalasztani, így a hagyományosan igazodási pontnak tekintett amerikai érdekekkel sem kerül szembe.

\section{FELHASZNÁLT IRODALOM}

1970. évi 12. törvényerejű rendelet, [online]. Forrás: Net.jogtar.hu [2019. 01. 23.]

Alberque, William: The NPT and the origins of NATO's nucelar sharing arrangements, Proliferation Papers, 2017/57, 1-58. o.

AlCARo, Ricardo: The Italian Government and NATO’s New Strategic Concept, [online], 2010. 06. Forrás: Iai.it [2019. 01.30.]

Ciarrapico, Antonio: Rapporti Est-Ovest 1977-79. La vicenda degli Euromissili, Rivista di Studi Politici Internazionali, 69. évf., 2002/3, 363-380. o.

CsERHÁTi András: A leépítők - osztrák, olasz, német, svájci és japán atomenergia, Nukleon, 5. évf., 2012/115, 1-9. o.

FORADORI, Paolo: Reluctant disarmer: Italy's ambiguous attitude toward NATO's nuclear weapons policy, European Security, 23. évf., 2014/1, 33-36. o. DOI: https://doi.org/10.1080/09662839.2013.851674

ForADORI, Paolo: Tactical Nuclear Weapons in Italy: Striking a Balance between Disarmament Aspirations and Alliance Obligations, The Nonproliferation Review, 19. évf., 2012/1, 13-29. DOI: https://doi.org/10.10 80/10736700.2012.655083

Governi italiani dal 1943 ad oggi: Governo D’Alema, [online]. Forrás: Governo.it [2018. 12. 05.]

Halmosy Dénes: Nemzetközi szerződések 1945-1982. A második világháború utáni korszak legfontosabb külpolitikai szerzödései, Közgazdasági és Jogi Könyvkiadó, Budapest, 1982, 105-113. o.

Kogan, Norman: The Revision of Italian Peace Treaty, Indiana Law Journal, 28. évf., 1953/3, 353-355. o.

LÁszLó Réka: Kormányzati instabilitás és a politikai rendszer stabilitása. A pártokrácia hatása az olasz politikai rendszerre, Politikatudományi Szemle, 15. évf., 2006/1, 69-92. o.

Manlio, Dinucci: Colpo di sonno nucleare, [online], 2017. 02. 28. Forrás: Peacelink.it [2019. 02. 03.]

MERLINI, Cesare: A concise history of nuclear Italy, The International Spectator: Italian Journal of International Affairs, 23. évf., 1988/3, 135-152. o. DOI: https://doi.org/10.1080/03932728808456649

Molnár Anna: Olaszország története a második köztársaság idején. Áron Kiadó, Budapest, 2011.

MoRetTi, Massimiliano: A never ending story: the Italian contribution to FIG. In: BINI, Elisabetta - LONDERo, Igor (eds.): Nuclear Italy - An International History of Italian Nuclear Policies during the Cold War, EUT, Edizioni Universitá di Trieste, Trieszt, 2017, 105-119. o.

Moro, Renato: Against the Euromissiles: Anti-nuclear Movements in 1980s Italy (1979-1984). In: BINI, Elisabetta - LONDERo, Igor (eds.): Nuclear Italy - An International History of Italian Nuclear Policies during the Cold War, EUT, Edizioni Universitá di Trieste, Trieszt, 2017, 199-211. o.

NATO Strategic Concept, [online], 1999. 04. 24. Forrás: Nato.int [2019. 02. 04.]

Nıølstad, Olav (ed.): The Last Decade of the Cold War: From Conflict Escalation to Conflict Transformation, Frank Cass,London - New York, 2005. DOI: https://doi.org/10.4324/9780203646205

NorRIS, Robert S. - KRISTENSEN, Hans M.: US tactical nuclear weapons in Europe, Bulletin of the Atomic Scientists, 61. évf., 2012/1, 69. o.

Nuti, Leopoldo: Italy's nuclear choices, UNISCI Discussion Papers, 2011/25, 170-172. o.

RonzitTi, Natalino: Le basi americane in Italia - problemi aperti, Dossier per il Senato della Repubblica, $X V^{\circ}$ Legislatura, 2007/70, 2-11. o. 
Southern European Task Force (SETAF), [online]. Forrás: Globalsecurity.org [2019. 01. 04.]

Spagnuolo, Laura: Italy’s Tactical Nuclear Weapons, [online], 2011. 05. 20. Forrás: Basicint.org [2019. 02. 04.]

Stratcom: Nuclear Weapons in Europe: Survey Results in Five European Countries, [online], 2006. 05. 26.

Forrás: Nonaumissilem51.org [2019. 02.04.]

The Simons Foundation: Global Public Opinion on Nuclear Weapons, [online], 2007. Forrás:

TheSimonsFoundation.ca [2019. 02 14.]

TrezzA, Carlo: M5S/Lega: linee di politica estera parzialmente convergenti, [online], 2018. 10. 08. Forrás: Affariinternazionali.it [2019. 02. 05.]

Wohlstetter, Albert: Nuclear Sharing: Nato and the N+1 Country, [online], 1961. 04. Forrás:

ForeignAffairs.com [2019. 01. 05.] DOI: https://doi.org/10.2307/20029495 